\title{
Effect of Lunasia amara Blanco on Sperm Number, Sperm Motility, and Testicular Histology of Male Rats
}

\author{
Muhammad Ja'far Luthfi \\ Biology Department, Faculty of Science and Technology, UIN Sunan Kalijaga \\ Jl. Marsda Adisucipto No 1 Yogyakarta 55281, Indonesia. Tel. +62-274-540971, Fax. +62-274-519739 \\ Author correspondency: \\ jafarluthfi@yahoo.com
}

\begin{abstract}
Sanrego (Lunasia amara), has been used in the folk medicine to increase and/or to treat male fertility. However there is no scientific evidence to confirm the positive effect of the plant on an improvement of male fertility. The objective of this research was to study the effects of the plant (on adult Sprague-Dawley male rats) at the doses of $30 \mathrm{mg} / \mathrm{kg}, 60 \mathrm{mg} / \mathrm{kg}$, and $90 \mathrm{mg} / \mathrm{kg}$ on the sperm count, motility, and testicular histology. Administration were given by force-feeding between 10.00 am and $12.00 \mathrm{pm}$ daily for a period of 42 days followed by sperm quality analysis and testicular histology evaluation. The sperm analysis showed that the sanrego increased the sperm count and sperm motility. The testicular histology also revealed positive effect of the plant on spermatogenesis. Overall the present study showed the sanrego is potential plant to increase male fertility.
\end{abstract}

Keywords: Sanrego, male fertility, testis histology, sperm quality, sperm number, sperm motility

\section{Introduction}

Male infertility is an increasingly problem in the modern world. Inspite of the many effort that have been employed over the years, medical treatment of male infertility has been a failure (Hamadeh, 2001; Kohn, 2001). In majority of cases of male infertility, the cause is low sperm quality (Shen and Ong, 2000; Clouatre, 2005).

One of the important factor that influence fertility are environment. Unlike genetic causes of male factor subfertility, environmental causes of subfertility are of particular interest, because of the possibility of its curative or preventive properties (Ebisch et al., 2006). A significant environmental factor is nutrition. It is in this area that natural remedies could shine. Animal studies have demonstrated the importance of the effects of nutrition on spermatogenesis (MacKay 2004; Sinclair, 2000).

Plant have been used by human since time of unmemorable. However, most claims that plant could enhance virility, increase fertility, or arouse sex libido are root in folklore with very little scientific evidence to support them (Anonym, 2005; Nickel, 2001). Despite gap between science and traditional medicine, there are historical evidence to the betterment of the sexual function by medicinal plant used by many culture (Waddell, 1980).

Sanrego (Lunasia amara Blanco) has been used by local people in some area of Sabah (Goh et al., 1997), Philipina and Indonesia (Perry, 1980) as folk medicine to cure many ailment. The plant use to treat snake bite, skin diseases, swollen limb, also as a remedy for stomach trouble (Perry, 1980). In the recent years, however, there is an extention of the plant's initial use. Based on observation on the goodness of the sexual function of horse graze on sanrego, Sulawesian people popularized sanrego to treat male sexual problem. Some studies were conducted to determine the effect of sanrego on male reproductive system of rat (Darise, 1999; Sutanto, 2002). However the result was far from complete. A systematic approach to provide scientific evidence to confirm the claims of the traditional used is greatly needed.

The present study was designed to determine the effect of an aqueous extract of Lunasia amara Blanco stem on the sperm quality and testicular histology of male rats.

\section{Materials and Methods}

\section{Animals}

Fifteen weeks male Sprague-Dawley rats from the animal house of the University Kebangsaan Malaysia were used. Animals were housed under standarized conditions. Rats were divided at random into 4 groups including control. Six rats per group received $0,30,60$, or $90 \mathrm{mg} / \mathrm{kg}$ aqueous extract of sanrego each day for 42 days.

\section{Preparation of aqueous extract of sanrego}

Sanrego was obtained from South Sulawesi, Indonesia. The plant was identified by Djoko Santoso, a botanist of the Departement of Pharmaceutical Biology, Gadjah Mada University. The voucher number 53/BIOFAR/020307 was deposited at the department. Aqueous extract was prepared according to a traditional method (Gonzales, et. al., 2004; Gonzales et al., 2006). In brief, $500 \mathrm{~g}$ of the dry powder of sanrego stem were placed in a container with $1500 \mathrm{~mL}$ of distilled water and boiled for 30 minutes. The extract was left to cool and 
was then filtered. The filtrate then freeze-dried and kept in $4^{\circ} \mathrm{C}$ refrigerator until use.

\section{Sperm Analysis}

Cauda epididymis were separated according to the Hamilton (1975). Sperm counts were determined using Improve Neubauer Hemocytometer as described previously (Prasad et al., 1972; NAFA \& ESHRE-SIGA, 2002) with some modification. In brief, cauda epididimis was minced in $15 \mathrm{ml} \mathrm{BWW}$ medium (Biggers et al., 1971) and incubated with $5 \% \mathrm{CO} 2$ for 30 minutes at $370 \mathrm{C}$. Data were expressed as number of sperm per cauda epididymis. Progressive sperm motility was assesed subjectively based on WHO laboratory manual (1999).

\section{Treatment}

To administer sanrego or vehicle, an appropriate oral needle were used to give, once a day, $2 \mathrm{ml}$ aqueous sanrego extract or distilled water. One day after cessation of treatment, the rats were sacrificed. The left cauda epididymides were removed and cleared off the attached fat and connective tissue. The cauda epididymides were prepared for sperm analysis. The testis were prepared for histological preparation.

\section{Testicular Histology}

After fixation in Bouin's solution, testes were transferred to $70 \%$ ethanol, embedded in paraffin and cut at $5 \mu \mathrm{m}$. Sections were stained with hematoxilin and eosin and digital images of sections were captured using an Olympus BX51 microscope and software analysis pro. Morphometrical evaluation was done using CorelDRAW $\mathrm{X} 3$ version 13. The diameter of seminiferous tubules was measured in 15 round tubular sections per animal $(n=3$ rats/group) at $100 \times$.

\section{Statistical Analysis}

Data are expressed as mean + S.D. and analysed for statistical significance by using one-way analysis of variance (ANOVA). When $F$ test was found significant $(\mathrm{P}<0.05)$, the data were further subjected to the Tukey Test. Data of seminiferous tubule measurement were analyzed using T-test. Data were analyzed using software SPSS 14.0.

\section{Results and Discussion}

The average sperm number of rats consuming Sanrego at dose $30 \mathrm{mg} / \mathrm{kg}(43.4375 \pm 5.22280 \times 106)$, dose $60 \mathrm{mg} / \mathrm{kg}$ $(49.3000 \pm 2.43475 \times 106)$, and dose $90 \mathrm{mg} / \mathrm{kg}(47.000 \pm$ $1.59992 \times 106$ ) were significantly increased compared to the average number of sperms from control groups $(35.3375 \pm 4.74091 \times 106)$ (table 1). The sperm number from rats consuming sanrego at dose $60 \mathrm{mg} / \mathrm{kg}$ was higher than sperm number from rats consuming sanrego at dose $90 \mathrm{mg} / \mathrm{kg}$. However, this were not significantly different.
The increase of sperm number indicates the beneficial effect of sanrego on testicular spermatogenesis. However, histological testicle analysis are needed to verify this observation.

Table 1. Sperm count and motility grade of rats after 42 days treatment with water extract of Sanrego.

\begin{tabular}{llll}
\hline Treatment & Dose & $\begin{array}{l}\text { Sperm count } \\
(\mathbf{x ~ 1 0})\end{array}$ & $\begin{array}{l}\text { Motility } \\
\text { grade }\end{array}$ \\
\hline Control & Distilled water & $35.3375 \pm 4.74091$ & $\mathrm{~b}$ \\
Sanrego & $30 \mathrm{mg} / \mathrm{kg}$ & $43.4375 \pm 5.22280$ & $\mathrm{~b}$ \\
& $60 \mathrm{mg} / \mathrm{kg}$ & $49.3000 \pm 2.43475$ & $\mathrm{a}$ \\
& $90 \mathrm{mg} / \mathrm{kg}$ & $47.000 \pm 1.59992$ & $\mathrm{a}$ \\
\hline
\end{tabular}

Note for the grade of motility WHO (1999)

(a): rapid progressive motility ; $\geq 25 \mu \mathrm{m} / \mathrm{s}$, (b): slow or sluggish progressive motility, (c): non progressive motility ; $<5 \mu \mathrm{m} / \mathrm{s}$, (d): immotile

The effect of sanrego on the sperm motility were showed in Table 1. The treatment groups have the betterment of sperms motility compared to the control groups. Treatment of Sanrego with dose $60 \mathrm{mg} / \mathrm{kg}$ and dose $90 \mathrm{mg} / \mathrm{kg}$ showed 'a' grade movement, while control group showed ' $b$ ' grade movement.

Sperm motility has been considered as one of the most important predictors of fertility. Several reports have demonstrated the correlation of motion parameters with fertilization rates (Liu et al., 1991). Further studies are required to confirm the mechanisms of action of sanrego on sperm motility.

Table 2. Average of seminiferous tubules diameter of control rats group compare to treatment group.

\begin{tabular}{lc} 
Group & Tubules seminiferuos diameter average \pm SD \\
\hline $\begin{array}{l}\text { Control } \\
\begin{array}{l}\text { Dose } 60 \\
\mathrm{mg} / \mathrm{kg}\end{array}\end{array}$ & $44.587 \pm 3.096$ \\
\hline
\end{tabular}

Treatment group provided significant increases in the diameter of seminiferous tubules $(48.969 \pm 3.504)$ when compared to the control group $(44.587 \pm 3.096)(\mathrm{P}<$ 0.005 ) (Table 2). This result was coincide with the sperm number and sperm motility analysis.

In general, the present study revealed that aqueous extract of sanrego enhanced the sperm motility, and seminiferous tubules diameter in rats. This biological activity may be due to one or more of the compound/phytochemicals present in the extract. At least ten alkaloids and quinolines are among the constituent of sanrego (Goodwin, 1959). This could directly or indirectly lead to an increase in the potential of fertility in male rats, mainly by acting directly on the pituitary gland and influencing its secretion and/or the pituitary glandspermatogenic axis. However, there is still unknown which particular metabolite of the sanrego has effect on 
the variables studied. Further studies are required and are in progress to isolate and identify the active principle(s) that acts upon this axis, influencing and increasing this process and the precise mode of its action.

\section{Conclusion}

In conclusion, this study support the extention of the traditional use of this herb to treat male fertility problem. The sperm count analysis showed that the sanrego increased the sperm count, progressive motility, and seminiferous tubules diameter. Overall the present study showed that sanrego is potential herb to increase male fertility.

\section{References}

Anonym, 2005. Aphodisiac galore? Total Health 27 (1): 7

Adimoelja, A. 2000. Phytochemicals and the breakthrough of traditional herbs in the management of sexual dysfunctions. Int. J. Androl. 23, suppl.2: 82-84

Biggers, J.D., Whitten, W.K. and Whittingham, D. 1971. The culture of mouse embryos in vitro. In Methods in Mammalian Embryology pp86-116. Ed. JC Daniel. Freeman, San Francisco, CA.

Clouatre, D. 2005. New help male fertility. Total Health 26/4: 2627

Darise, M. 1999. Obat kuat: Berkuda dengan sanrego. Gatra 23: 13.

Ebisch, I.M.W., F.H. P. Pierik, F.H. De Jong, C.M.G. Thomas, R.P.M. Steegers-Theunissen. 2006. Does folic acid and zinc sulphate intervention affect endocrine parameters and sperm characteristics in man? Int. J. Andr. 29(2): 339-345

Foster, S., J.A. Duke. 2000. A Field Guide to Medicinal Plants and Herbs. Second Edition. Houghton Mifflin Company. Boston.

Goh, S.H., K.H. Lee, C.H. Chuah. 1997. Phytochemical study of Borneo: Selected plants from Sabah lowland forest. J. Herbs Spices Med. Pl. 5: 29-52

Goodwin, S., A. F. Smith, A. A. Velasquez, E. C. Horning. 1959. Alkaloids of Lunasia umara Blanco. Isolation Studies. J. Am. Chem. Soc. 81: 6209-6213

Hamadeh, M. E., T. Zeginiadov, P. Rosenbaum. 2001. Predictive value of sperm chromatin condensation (aniline blue staining) in the assessment of male fertility. Archives of Andrology 46: 99-104

Hamilton, D.W. 1975. Structure, function of the epithelium lining the ductuli efferents, ductus epididymis and ductus deferens in the rat. In: Handbook of Physiology, Section VII, Endocrinology, vol.5, Male Reproductive System (eds D.W. Hamilton and R.O. Greep). Pp. 259-301. American Physiological Society, Washington D.C.

Humason, G.L. 1979. Animal tissue techniques. Freeman and Company. San Fransisco.

Kohn, F.M. 2001. Nonmedical and naturopathic approaches to treatment of male fertility. In Proceedings of the 7th Andrology Symposium. Treatment of male infertility - viewpoints, controversies, perspectives. Giessen, Germany. p: 337

Liu, D. Y., Clarke, G. N., \& Baker, H. W. G. (1991). Relationship between sperm motility assessed with the Hamilton-Thorn motility analyzer and fertilization rates in vitro. Journal of Andrology, 12, 231-239.

MacKay, D. 2004. Nutrients and botanicals for erectile dysfunction: examining the evidence. Alter. Med. Rev. 9 (1): 4 $-16$

NAFA, ESHRE-SIGA. 2002. Manual on basic semen analysis.

Pei, J., E. Strehler, U. Noss, M. Abt, P. Piomboni, B. Baccetti, K. Sterzik. 2005. Quantittive evaluation of spermatozoa ultrastructure after acupunture treatment for idiopathic male infertility. Fertility and Sterility 84(1) : 141-147

Perry L. M. 1980. Medicinal plants of east and Southeast Asia: Attribute, properties and uses. The M.I.T Press. Massachusetts.

Prasad, M. R. N., N.J. Chinoy, K.M. Kadam. 1972. Changes in succinic dehydrogenase levels in the rat epididymis under normal and altered physiologic conditions. Fertility and Sterility 23 (3): 186-190.

Shen, H., C. Ong. 2000. Detection of oxidative DNA damage in human sperm and its association with sperm function and male infertility. Free Radical Biology and Medicine 28(4): 529-536

Sinclair, S. 2000. Male infertility: Nutritional and Environmental Considerations. Alternative Medicine Review 5 (1): 28-38.

Sutanto, H. 2002. Uji efek androgenik ekstrak kayu sanrego (Lunasia amara Blanco) pada tikus jantan.. Tesis Sarjana. Universitas Katholik Widya Mandala Surabaya. Unpublished.

Nickel, L.N. 2001. Nature's Aphrodisiacs. Crossing Press. USA

Waddell, T.G., H. Jones, A. L. Keith. 1980. Legendary chemical aphrodisiacs. Journal of Chemical Education 57(5): 341-342.

WHO. 1999. Laboratory manual for the examination of human semen and semen-cervical mucus interaction. New York: Cambridge University Press. 
